\title{
Bioactive Withanolides from Withania obtusifolia
}

By: Feras Q. Alali, Chiraz Soumia M. Amrine, Tamam El-Elimat, Ahmad Alkofahi, Khaled Tawaha, Mohammad Gharaibah, Steven M. Swanson, Joseph O. Falkinham III, Marisa Cabeza, Araceli Sánchez, Mario Figueroa, and Nicholas H. Oberlies

Feras Q. Alali, Chiraz Soumia M. Amrine, Tamam El-Elimat, Ahmad Alkofahi, Khaled Tawaha, Mohammad Gharaibah, Steven M. Swanson, Joseph O. Falkinham III, Marisa Cabeza, Araceli Sánchez, Mario Figueroa, and Nicholas H. Oberlies. "Bioactive Withanolides from Withania obtusifolia." Phytochemistry Letters, 2014, 9, 96-101. doi:10.1016/j.phytol.2014.05.002

Made available courtesy of Elsevier: $\underline{\text { https://doi.org/10.1016/j.phytol.2014.05.002 }}$

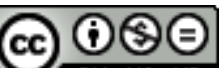

EY NC ND This work is licensed under a Creative Commons AttributionNonCommercial-NoDerivatives 4.0 International License.

$* * *$ (C) 2014 Phytochemical Society of Europe. Reprinted with permission. This version of the document is not the version of record. Figures and/or pictures may be missing from this format of the document. ***

\section{Abstract:}

Seven withanolides were isolated from the leaves of Withania obtusifolia. Of these, one was new [obtusifonolide (1)], five were new to the species [sitoindoside IX (2), $6 \alpha$-chloro-5 $\beta$-hydroxy withaferin A (3), isowithanone (4), 2,3-dihydro-3-ethoxywithaferin A (5), and daturataturin A (6)], and one was reported previously from $W$. obtusifolia [withaferin A (7)]. The structures were elucidated using a set of spectroscopic and spectrometric techniques. Compounds (1-7) were evaluated for cytotoxicity against a human cancer cell panel and for antimicrobial activity in an array of bacteria and fungi. Compound 7 showed cytotoxic activity against the MDA-MB-435 (human melanoma) and SW-620 (human colon cancer) cell lines with $\mathrm{IC}_{50}$ values of 1.7 and $0.3 \mu \mathrm{M}$, respectively. The in vitro activity of 7 on $17 \beta$-hydroxysteroid dehydrogenase and $5 \alpha-$ reductase was also investigated.

Keywords: Withania obtusifolia | Cytotoxicity | Withanolides | Withaferin A | 17ßHydroxysteroid dehydrogenase $\mid 5 \alpha$-Reductase

\section{Article:}

\section{Introduction}

The withanolides are a group of naturally occurring polyoxygenated C-28 ergostane-type steroids (Chen et al., 2011, Lavie et al., 1965). A common feature among most of them is the oxidation at C-1, C-22, and C-26 (Chen et al., 2011). Withanolides occur largely, but not exclusively, in genera belonging to the plant family Solanaceae, including Withania, Lycium, Datura, Dunalia, Acnistus, Jaborosa, Nicandra, and Physalis (Misico et al., 2011). Withaferin A, isolated in 1965, was the first withanolide to be characterized from Withania somnifera (Lavie 
et al., 1965) and from Acnistus arborescens (Kupchan et al., 1965). It showed in vitro and in vivo cytotoxic activity against an array of tumor cells (Glotter, 1991, Samadi et al., 2010).

Withanolides can be divided into two types, those with a $\delta$-lactone or $\delta$-lactol, resulting from appropriate oxidation of C-22 and C-26, and those with a $\gamma$-lactone or $\gamma$-lactol involving C-23 and C-26; most of the withanolides belong to the former type (Chen et al., 2011, Glotter, 1991, Misico et al., 2011). Biogenetic transformations of the steroidal skeleton and the side chain have diversified the structures of withanolides (Chen et al., 2011, Glotter, 1991, Misico et al., 2011). Withanolides have attracted attention due to their wide range of biological activities, including antitumor, anti-inflammatory, antifeedant, antimicrobial, cytotoxic, immunomodulating, and cancer chemopreventive activities (Chen et al., 2011, Glotter, 1991, Misico et al., 2011). Moreover, recent studies have suggested that withanolides may also act as growth regulators due to their common biosynthetic origin with brassinosteroids, a well-known class of growth regulators (Sangwan et al., 2008).

As part of an ongoing project to explore medicinal plants of Jordan for anticancer leads (Alali et al., 2005, Alali et al., 2008, Alali et al., 2010), seven withanolides (1-7), of which one was new, were isolated and characterized from an ethanolic extract of the leaves of Withania obtusifolia.

\section{Results and discussion}

Dried leaves of $W$. obtusifolia were extracted with EtOH and partitioned with organic solvents to yield five fractions (F01-F05). Fraction F05 was purified using silica gel column

chromatography to yield 241 sub-fractions, and similar ones were combined into 11 pools. Pools P08 and P10 were subjected to gel filtration on Sephadex LH-20 to yield a total of 7 and 5 subfractions, respectively. Sub-fractions P08-5 and P10-3 were found to be rich in withanolides as evidenced by thin layer chromatography (TLC), and were purified further using preparative and semipreparative reversed-phase high performance liquid chromatography (RP-HPLC) to yield seven compounds (1-7) with $>95 \%$ purity as evidenced by ultra-performance liquid chromatography (UPLC) (Fig. S1, Supplementary data).

Six known withanolides were identified by 1- and 2-dimensional nuclear magnetic resonance (1and 2D-NMR), high-resolution mass spectrometry (HRMS) analyses, and comparisons to literature data: sitoindoside IX (2) (Ghosal et al., 1988), 6 $\alpha$-chloro-5 $\beta$-hydroxy withaferin A (3) (Nittala et al., 1981), isowithanone (4) (Lala et al., 2006), 2,3-dihydro-3-ethoxywithaferin A (5) (Pelletier et al., 1979), daturataturin A (6) (Shingu et al., 1990), and withaferin A (7) (Lavie et al., 1965). This is the first report of compounds 2-6from $W$. obtusifolia.

Compound 1 (5.43 mg) was obtained as an off-white powder. The molecular formula was deduced as $\mathrm{C}_{30} \mathrm{H}_{40} \mathrm{O}_{6}$ via high-resolution electrospray ionization mass spectrometry(HRESIMS), establishing an index of hydrogen deficiency of 11 . The (+)-atmospheric pressure chemical ionization mass spectrum (APCIMS) displayed peaks at $m / z 479.53\left[\mathrm{M}+\mathrm{H}-\mathrm{H}_{2} \mathrm{O}\right]^{+}, 437.60$ $[\mathrm{M}+\mathrm{H}-\mathrm{OHAc}]^{+}, 419.38\left[\mathrm{M}+\mathrm{H}-\mathrm{OHAc}-\mathrm{H}_{2} \mathrm{O}\right]^{+}, 401.41\left[\mathrm{M}+\mathrm{H}-\mathrm{OHAc}-2 \mathrm{H}_{2} \mathrm{O}\right]^{+}, 383.35$ $\left[\mathrm{M}+\mathrm{H}-\mathrm{OHAc}-3 \mathrm{H}_{2} \mathrm{O}\right]^{+}, 267.55[\mathrm{M}-\mathrm{OHAc}-\text { lactone }]^{+}$, and $249.34\left[\mathrm{M}-\mathrm{OHAc}-\text { lactone }-\mathrm{H}_{2} \mathrm{O}\right]^{+}$, a characteristic withanolide fragmentation pattern (Atta-ur-Rahman et al., 2003, Llanos et al., 2010). The ${ }^{1} \mathrm{H}$ NMR data of 1 revealed the presence of three olefinic protons $\left(\delta_{\mathrm{H}} 5.87\right.$, 
$\mathrm{dd}, J=10.3,2.3 \mathrm{~Hz} ; 6.78, \mathrm{~m}$; and 5.55, d, $J=5.7 \mathrm{~Hz}$, for H-2, H-3, and H-6, respectively), two oxymethines $\left(\delta_{\mathrm{H}} 4.89, \mathrm{t}, J=7.5 \mathrm{~Hz}\right.$; and $4.24, \mathrm{dt}, J=13.2,3.4 \mathrm{~Hz}$, for $\mathrm{H}-16$ and $\mathrm{H}-22$, respectively), one oxymethylene $\left(\delta_{\mathrm{H}} 4.34, \mathrm{~d}, J=5.7 \mathrm{~Hz}\right.$, for $\left.\mathrm{H}_{2}-27\right)$, five methines $\left(\delta_{\mathrm{H}} 1.43, \mathrm{~m}\right.$; $1.69, \mathrm{~m} ; 1.41, \mathrm{~m} ; 1.46, \mathrm{~m}$; and 2.16, $\mathrm{m}$, for $\mathrm{H}-8, \mathrm{H}-9, \mathrm{H}-14, \mathrm{H}-17$, and $\mathrm{H}-20$, respectively),

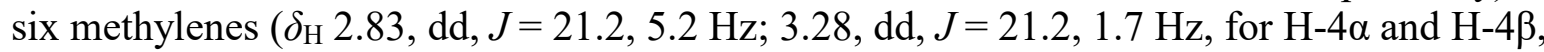
respectively; $1.57, \mathrm{~m} ; 1.92, \mathrm{~m}$, for $\mathrm{H}-7 \alpha$ and $\mathrm{H}-7 \beta$, respectively; $1.48, \mathrm{~m} ; 2.23, \mathrm{~m}$, for $\mathrm{H}-11 \alpha$ and $\mathrm{H}-11 \beta$, respectively; $1.48, \mathrm{~m} ; 2.01$, $\mathrm{m}$, for $\mathrm{H}-12 \alpha$ and $\mathrm{H}-12 \beta$, respectively; $1.51, \mathrm{~m} ; 1.83$, $\mathrm{m}$, for $\mathrm{H}-15 \alpha$ and $\mathrm{H}-15 \beta$, respectively; and $2.25, \mathrm{~m} ; 2.51, \mathrm{dd}, J=13.8,13.2 \mathrm{~Hz}$, for $\mathrm{H}-23 \alpha$ and $\mathrm{H}-23 \beta$, respectively), five methyls $\left(\delta_{\mathrm{H}} 0.79, \mathrm{~s} ; 1.23, \mathrm{~s} ; 1.06, \mathrm{~d}, J=6.3 \mathrm{~Hz} ; 2.03\right.$, s; and 1.96, s, for $\mathrm{CH}_{3}-$ $18, \mathrm{CH}_{3}-19, \mathrm{CH}_{3}-21, \mathrm{CH}_{3}-28$, and $\mathrm{CH}_{3}-30$, respectively), and one exchangeable proton $\left(\delta_{\mathrm{H}} 2.88\right.$, $\mathrm{t}, J=5.7 \mathrm{~Hz}$, for $27-\mathrm{OH}$ ) (Table 1). The ${ }^{13} \mathrm{C}$ NMR data revealed 30 carbons, consistent with the HRMS data and indicative of three carbonyls $\left(\delta_{\mathrm{C}} 204.5,167.0\right.$, and 170.3 , for C-1, C-26, and C29 , respectively), six olefinic carbons $\left(\delta_{\mathrm{C}} 127.9,145.4,136.1,124.5,152.7\right.$, and 125.9, for C-2, C-3, C-5, C-6, C-24, and C-25, respectively), two oxymethines $\left(\delta_{\mathrm{C}} 79.9\right.$ and 78.8 , for C-16 and $\mathrm{C}-22$, respectively), one oxymethylene $\left(\delta_{\mathrm{C}} 57.7\right.$ for $\left.\mathrm{C}-27\right)$, five methines $\left(\delta_{\mathrm{C}} 32.6,42.8,53.8\right.$, 57.4, and 37.5, for C-8, C-9, C-14, C-17, and C-20, respectively), six methylenes $\left(\delta_{\mathrm{C}} 33.5,30.7\right.$, 23.2, 39.8, 34.8, and 30.0, for C-4, C-7, C-11, C-12, C-15, and C-23, respectively), and five methyls $\left(\delta_{\mathrm{C}} 13.3,19.1,13.6,20.1\right.$, and 21.2 , for C-18, C-19, C-21, C-28, and C-30, respectively), and two quaternary carbons $\left(\delta_{\mathrm{C}} 50.5\right.$ and 43.6 , for $\mathrm{C}-10$ and $\mathrm{C}-13$, respectively) (Table 1$)$. The three double bonds and the three carbonyl groups accounted for six degrees of unsaturation, indicating that five rings must exist in the structure. Correlation spectroscopy (COSY) data identified two spin systems H-2/H-3/H-4 $\alpha$ and H-6/H-7/H-8/(H-9/H-11/H-12)/H-14/H-15/H16/H-17/H-20/(H-21)/H22/H-23. A heteronuclear multiple-bond correlation (HMBC) was observed from $\mathrm{H}-16$ to $\mathrm{C}-29$, indicating the connectivity of the acetoxy group, while the $\mathrm{HMBC}$ correlations observed from $\mathrm{CH}_{2}-27$ to $\mathrm{C}-24$ and $\mathrm{C}-26$ indicated the connectivity of the hydroxymethyl to C-25 (Fig. 2). In all known withanolides, the configuration of C-22 was assigned as $R$, which was deduced from the splitting pattern of $\mathrm{H}-22$. Herein, $\mathrm{H}-22$ appeared as a doublet of triplets with coupling constant of 13.2 and $3.4 \mathrm{~Hz}$, which was consistent with the $R$ configuration as reported previously. For example, the H-22 in withalongolide A, a withanolide that was isolated from the aerial parts of Physalis longifolia, appeared as a doublet of triplets with coupling constants of 13.3 and 3.4 Hz (Atta-ur-Rahman et al., 1998, Misra et al., 2005, Ray and Gupta, 1994, Zhang et al., 2011). The relative configuration at position 16 was established as $R$ via nuclear overhauser effect spectroscopy (NOESY) correlations that were observed between $\mathrm{H}-16$ and the protons at $\mathrm{C}-8$ and $\mathrm{C}-18$ (Fig. 2), indicating that these protons were in close proximity in space and that the orientation of the proton at $\mathrm{C}-16$ should be beta. These data suggested the structure of 1 as 16 $\alpha$-acetoxy-27-hydroxy-1-oxo(22R)witha-2,5,24-trienolide (Fig. 1), which was ascribed the trivial name obtusifonolide (1).

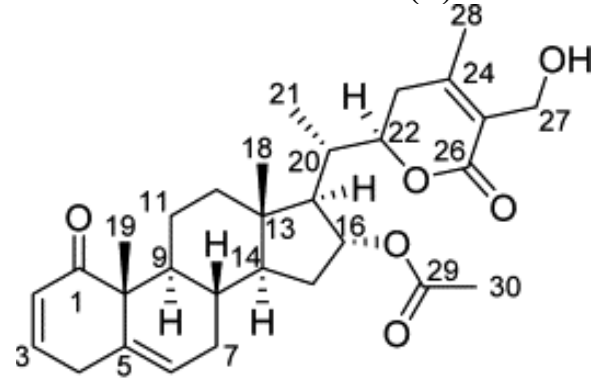

Fig. 1. Structure of compound 1. 
Table 1. ${ }^{1} \mathrm{H}(500 \mathrm{MHz})$ and ${ }^{13} \mathrm{C}(125 \mathrm{MHz}) \mathrm{NMR}$ data for obtusifonolide (1) in $\mathrm{CDCl}_{3}$.

\begin{tabular}{|c|c|c|}
\hline Position & $\delta_{\mathrm{C}}$ & $\delta_{\mathrm{H}}$, mult $(J$ in $\mathrm{Hz})$ \\
\hline 1 & 204.5 & - \\
\hline 2 & 127.9 & $5.87, \mathrm{dd}(10.3,2.3)$ \\
\hline 3 & 145.4 & $6.78, \mathrm{~m}$ \\
\hline \multirow[t]{2}{*}{4} & 33.5 & 2.83, dd $(21.2,5.2)$ \\
\hline & & $3.28, \mathrm{dd}(21.2,1.7)$ \\
\hline 5 & 136.1 & - \\
\hline 6 & 124.5 & $5.55, \mathrm{~d}(5.7)$ \\
\hline \multirow[t]{2}{*}{7} & 30.7 & $1.57, \mathrm{~m}$ \\
\hline & & $1.92, \mathrm{~m}$ \\
\hline 8 & 32.6 & $1.43, \mathrm{~m}$ \\
\hline 9 & 42.8 & $1.69, \mathrm{~m}$ \\
\hline 10 & 50.5 & - \\
\hline \multirow[t]{2}{*}{11} & 23.2 & $1.48, \mathrm{~m}$ \\
\hline & & $2.23, \mathrm{~m}$ \\
\hline \multirow[t]{2}{*}{12} & 39.8 & $1.48, \mathrm{~m}$ \\
\hline & & $2.01, \mathrm{~m}$ \\
\hline 13 & 43.6 & - \\
\hline 14 & 53.8 & $1.41, \mathrm{~m}$ \\
\hline \multirow[t]{2}{*}{15} & 34.8 & $1.51, \mathrm{~m}$ \\
\hline & & $1.83, \mathrm{~m}$ \\
\hline 16 & 79.9 & $4.89, \mathrm{t}(7.5)$ \\
\hline 17 & 57.4 & $1.46, \mathrm{~m}$ \\
\hline 18 & 13.3 & $0.79, \mathrm{~s}$ \\
\hline 19 & 19.1 & $1.23, \mathrm{~s}$ \\
\hline 20 & 37.5 & $2.16, \mathrm{~m}$ \\
\hline 21 & 13.6 & $1.06, \mathrm{~d}(6.3)$ \\
\hline 22 & 78.8 & $4.24, \mathrm{dt}(13.2,3.4)$ \\
\hline \multirow[t]{2}{*}{$\frac{22}{23}$} & 30.0 & $2.25, \mathrm{~m}$ \\
\hline & & $2.51, \mathrm{dd}(13.8,13.2)$ \\
\hline 24 & 152.7 & - \\
\hline 25 & 125.9 & - \\
\hline 26 & 167.0 & - \\
\hline 27 & 57.7 & $4.34, \mathrm{~d}(5.7)$ \\
\hline 28 & 20.1 & $2.03, \mathrm{~s}$ \\
\hline 29 & 170.3 & - \\
\hline 30 & 21.2 & $1.96, \mathrm{~s}$ \\
\hline $27-\mathrm{OH}$ & & $2.88, \mathrm{t}(5.7)$ \\
\hline
\end{tabular}

Compounds 1-7 were tested for cytotoxicity against two cancer cell lines, MDA-MB-435 (human melanoma) and SW-620 (human colon cancer). Compound 7 showed cytotoxic activity against the MDA-MB-435 and SW-620 cell lines with $\mathrm{IC}_{50}$ values of 1.7 and $0.3 \mu \mathrm{M}$, respectively. Compounds 1-3 showed cytotoxic activities against the SW-620 cell line with $\mathrm{IC}_{50}$ values of $7.3,5.5$, and $7.1 \mu \mathrm{M}$, respectively, while the other compounds were inactive (Table 2). As predicted from previous structure-activity relationship studies (Zhang et al., 2011), compound 7, with the enone moiety in ring $\mathrm{A}$, the $5 \beta, 6 \beta$-epoxy group in ring $\mathrm{B}$, and the side chain lactone ring was the most potent among the isolates. Withanolide glycoside2 displayed less cytotoxic activity relative to its aglycone $\mathbf{7}$. When compounds $\mathbf{1 - 7}$ were tested for antimicrobial 
activity in an array of bacteria, yeast, and fungi, none of the compounds, except 7, demonstrated any activity (Table S1, Supplementary data).

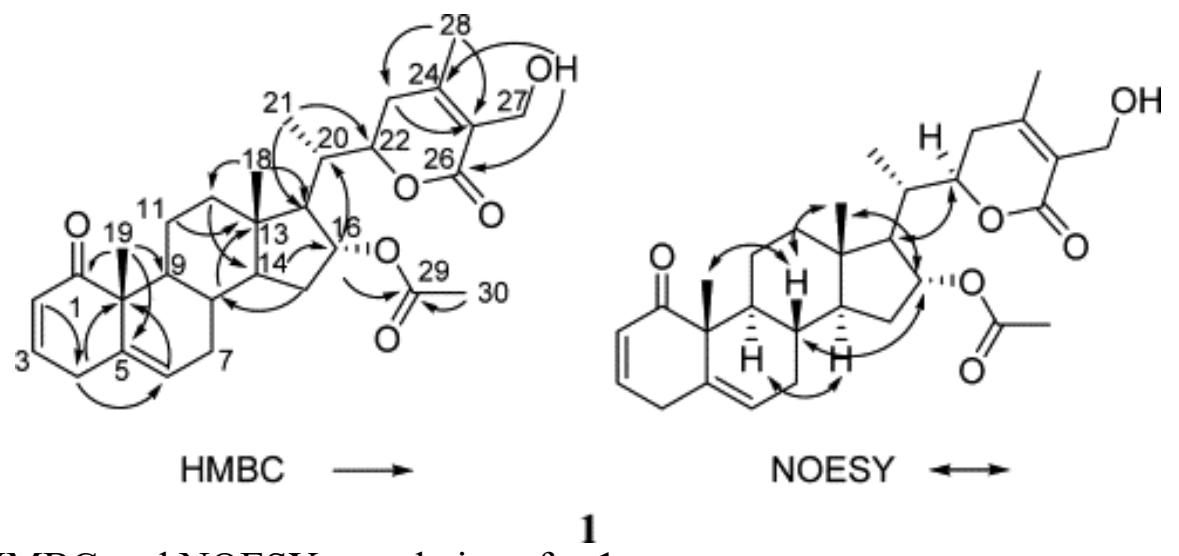

Fig. 2. Key HMBC and NOESY correlations for $\mathbf{1}$.

Table 2. Cytotoxicity of compounds $1-7$ against two cancer cell lines. ${ }^{\text {a }}$

\begin{tabular}{|l|l|l|}
\hline Compound & MDA-MB-435 & SW-620 \\
\hline $\mathbf{1}$ & $>10$ & 7.3 \\
\hline $\mathbf{2}$ & $>10$ & 5.5 \\
\hline $\mathbf{3}$ & $>10$ & 7.1 \\
\hline $\mathbf{4}$ & $>10$ & $>10$ \\
\hline $\mathbf{5}$ & $>10$ & $>10$ \\
\hline $\mathbf{6}$ & $>10$ & $>10$ \\
\hline $\mathbf{7}$ & 1.7 & 0.3 \\
\hline
\end{tabular}

${ }^{\mathrm{a}}$ Results were expressed as $\mathrm{IC}_{50}$ values $(\mu \mathrm{M})$. Positive control was vinblastine tested at $1 \mathrm{nM}$ for MDA-MB-435 and $10 \mathrm{nM}$ for SW620, which had 48\% and 30\% viable cells after treatment, respectively.

The biological effects of withaferin A (7) on the activity of $17 \beta$-hydroxysteroid dehydrogenase (17 $\beta$-HSD) and $5 \alpha$-reductase $(5 \alpha-R)$ were investigated. These enzymes have an important role in the biosynthesis of $5 \alpha$-dihydrotestosterone (DHT) and pathologies associated with the prostate gland (i.e. hyperplasia and prostate cancer) (Bonkhoff et al., 1996, Geissler et al., 1994, Marberger, 2006, Thomas et al., 2005). Type 5 17 $\beta$-HSD catalyzes the conversion of androstenedione into testosterone (Peltoketo et al., 1999). On the other hand, $5 \alpha-\mathrm{R}$ converts testosterone into the more potent androgen, dihydrotestosterone. The hyperplasia of the prostate gland and prostate cancer has been associated with high levels of serum DHT (Bonkhoff et al., 1996, Marberger, 2006, Thomas et al., 2005). Since different plant-derived $5 \alpha$-colestane molecules have been identified as selective inhibitors or anabolic agents with minimal or no androgenic side effects (Esposito et al., 2011), it was of interest to study the in vitro effect of withaferin A on the enzymes 17 $\beta$-HSD and $5 \alpha-$ R. Withaferin A (7) stimulated the activity of $17 \beta$-HSD and $5 \alpha-\mathrm{R}$ enzymes with half maximal effective concentration $\left(\mathrm{EC}_{50}\right)$ values of $63 \pm 8.7$ and $20 \pm 6.5 \mathrm{nM}$, respectively (Fig. 3). 

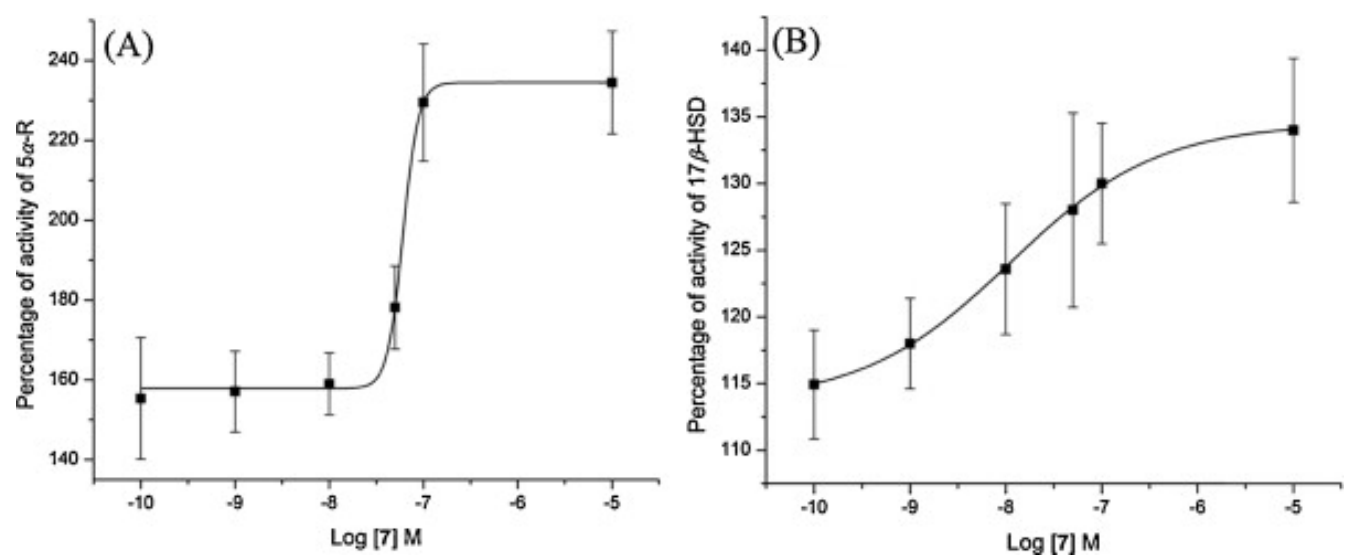

Fig. 3. Stimulatory withaferin A (7) EC 50 curves against (A) $5 \alpha-R$ and (B) $17 \beta-H S D$ enzymes.

\section{Experimental}

\subsection{General experimental procedures}

Optical rotations and UV spectra were acquired on a Rudolph Autopol III automatic polarimeter and a Varian Cary 100 Bio UV-Vis spectrophotometer. NMR experiments were conducted in either $\mathrm{CDCl}_{3}$ or methanol- $d_{4}$ with TMSi as a reference via a Bruker NMR spectrometer operating at $400 \mathrm{MHz}$ for ${ }^{1} \mathrm{H}$ and $100 \mathrm{MHz}$ for ${ }^{13} \mathrm{C}$ and a JEOL ECA-500 NMR spectrometer operating at $500 \mathrm{MHz}$ for ${ }^{1} \mathrm{H}$ and $125 \mathrm{MHz}$ for ${ }^{13} \mathrm{C}$. Low-resolution ESIMS data were measured with $\mathrm{PE}$ Sciex API 3200 mass spectrometer, while high-resolution ESIMS was performed on a Thermo LTQ Orbitrap XL mass spectrometer. UPLC was carried out on a Waters Acquity system with data collected and analyzed using Empower software. HPLC was carried out using either a Varian Prostar HPLC system equipped with ProStar 210 pumps and a Prostar 335 photodiode array detector (PDA), with data collected and analyzed using Galaxie Chromatography Workstation software (version 1.9.3.2) or on a Lachrom Merck-Hitachi, equipped with a quaternary gradient L-7150 pump, L-7455 diode-array detector, L-7200 autosampler, and D7000 interface. For preparative HPLC, a Phenomenex Gemini-NX $\mathrm{C}_{18}(4 \mu \mathrm{m} ; 250 \mathrm{~mm} \times 21.2$ $\mathrm{mm}$ ) column was used at a $21 \mathrm{ml} / \mathrm{min}$ flow rate, or a Hibar Merck prepacked column RT 250-25, Lichrosorb RP-18 $(7 \mu \mathrm{m})$ at a flow rate of $10 \mathrm{ml} / \mathrm{min}$. For the semi-preparative HPLC, a Phenomenex Gemini-NX $\mathrm{C}_{18}(4 \mu \mathrm{m} ; 250 \mathrm{~mm} \times 10 \mathrm{~mm})$ column was used at a $4.72 \mathrm{ml} / \mathrm{min}$ flow rate. For UPLC analysis, a Waters BEH $\mathrm{C}_{18}$ column $(1.7 \mu \mathrm{m} ; 50 \mathrm{~mm} \times 2.1 \mathrm{~mm})$ was used with a $0.6 \mathrm{ml} / \mathrm{min}$ flow rate. Column chromatography was performed using silica gel 60 (0.06-0.2 mm; 70-230 mesh) and Sephadex ${ }^{\circledR}$ LH-20. For thin layer chromatography, silica gel 60 with gypsum and pigment addition for UV or silica gel 60 with $15 \%$ calcium sulfate and fluorescent indicator were used. TLC spots were visualized using a UV lamp at $254 \mathrm{~nm}$ (Vilber Lourmat, $4 \mathrm{~W}-254 \mathrm{~nm}$ tube). All other reagents and solvents were obtained from either Fisher Scientific or SigmaAldrich and were used without further purification.

\subsection{Plant material}

Leaves, stems and fruits of $W$. obtusifolia were collected in October 2010 in the central part of

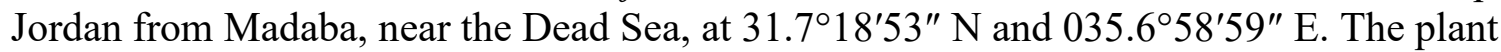
material was identified by Mohammad Gharaibah, Plant Taxonomist, Faculty of Agriculture, 
Jordan University of Science and Technology. A voucher specimen (PHS-117) was deposited in the herbarium of the Faculty of Pharmacy, Jordan University of Science and Technology, Irbid, Jordan.

\subsection{Extraction and isolation}

Air-dried leaves of $W$. obtusifolia were ground to a powder using a Retsch Mühle mill (RETSCH $\mathrm{GmbH}$, Haan, Germany). About $540 \mathrm{~g}$ of powdered leaves were extracted exhaustively with EtOH using a Soxhlet apparatus. The solvent was evaporated under reduced pressure to yield $70.01 \mathrm{~g}$ of EtOH extract (F01), which was reconstituted in $1.34 \mathrm{~L}$ of $\mathrm{CHCl}_{3}$ and partitioned 5 times with water (1:1) using a separatory funnel. The $\mathrm{CHCl}_{3}$ fraction (F03) was evaporated to dryness and the residue $(26.15 \mathrm{~g})$ was dissolved in $90 \% \mathrm{MeOH}$ and partitioned 5 times with nhexane (1:1) to yield $15.59 \mathrm{~g}$ of the defatted MeOH fraction (F05). F05 was subjected to chromatography over silica gel using a gradient of $100 \%$ hexane to $100 \% \mathrm{CH}_{2} \mathrm{Cl}_{2}$ to $25 \% \mathrm{MeOH}$ in $\mathrm{CH}_{2} \mathrm{Cl}_{2}$ to yield 11 pools (P01-P11). $\mathrm{P} 08$ and $\mathrm{P} 10$ eluted with $25 \% \mathrm{MeOH}$ in $\mathrm{CH}_{2} \mathrm{Cl}_{2}$ was found to be rich in withanolides as evidenced from TLC and hence subjected to further purification using gel filtration on Sephadex LH-20. The columns were eluted with $100 \%$ ethanol to afford 7 (P08-C01 to P08-C07) and 5 pools (P10-C01 to P10-C05), from P08 and P10, respectively. P08-C05 $(\sim 165 \mathrm{mg})$ was subjected to preparative HPLC using a gradient system of 35:65 to 45:55 of $\mathrm{CH}_{3} \mathrm{CN}-\mathrm{H}_{2} \mathrm{O}$ (acidified with $0.1 \%$ formic acid) over $20 \mathrm{~min}$ at a flow rate of $21.24 \mathrm{ml} / \mathrm{min}$ to yield eleven sub-fractions. Sub-fractions 1, 5, 6, and 10 yielded compounds 7(62.49 mg), 3 (6.07 mg), 4 (9.08 mg), and 1 (5.43 mg), which were eluted at 11.2, 14.5, 16.0, and $27.4 \mathrm{~min}$, respectively. Sub-fraction 7 was subjected to semipreparative HPLC using a gradient system of 60:40 to 65:35 of $\mathrm{MeOH}-\mathrm{H}_{2} \mathrm{O}$ (acidified with $0.1 \%$ formic acid) over $20 \mathrm{~min}$ at a flow rate of 4.72 and yielded compound $5(3.73 \mathrm{mg})$, which was eluted at $15.8 \mathrm{~min} . \mathrm{P} 10$ $\mathrm{C} 03$ from the dextran column $(\sim 125 \mathrm{mg})$ was subjected to further purification using preparative HPLC using a gradient system of 20:80 to $50: 50$ of $\mathrm{CH}_{3} \mathrm{CN}-\mathrm{H}_{2} \mathrm{O}$ (acidified with $0.1 \%$ formic acid) over $30 \mathrm{~min}$ at a flow rate of $21.24 \mathrm{ml} / \mathrm{min}$ to yield seven sub-fractions. Sub-fractions 2, 5 , and 6 yielded compounds $2(3.57 \mathrm{mg}), 6(2.89 \mathrm{mg})$, and $7(4.88 \mathrm{mg})$, which were eluted at 14.5, 21.1 , and $22.8 \mathrm{~min}$, respectively. The purity of the isolated compounds were evaluated using UPLC with a gradient solvent system that initiated with $20: 80 \mathrm{CH}_{3} \mathrm{CN}-\mathrm{H}_{2} \mathrm{O}$ to $100 \% \mathrm{CH}_{3} \mathrm{CN}$ over $4.5 \mathrm{~min}$; all compounds were $>95 \%$ pure (Fig. S1, Supplementary data).

\subsubsection{Obtusifonolide (1)}

Off-white powder (5.43 mg); $\alpha \mathrm{D} 26=+7.05\left(c 0.23, \mathrm{CHCl}_{3}\right) ; \mathrm{UV}(\mathrm{MeOH}) \lambda_{\max }(\log \varepsilon) 226(3.54)$ $\mathrm{nm} ;{ }^{1} \mathrm{H} \mathrm{NMR}\left(\mathrm{CDCl}_{3}, 500 \mathrm{MHz}\right)$ and ${ }^{13} \mathrm{C} \mathrm{NMR}\left(\mathrm{CDCl}_{3}, 125 \mathrm{MHz}\right)$, see Table 1; HR-ESI-MS $m / z$ 497.2891 $[\mathrm{M}+\mathrm{H}]^{+}$(calcd for $\mathrm{C}_{30} \mathrm{H}_{41} \mathrm{O}_{6} 497.2898$ ).

\subsection{Cytotoxicity assay}

Human cancer cell lines designated MDA-MB-435 (melanoma) and SW-620 (colon) were purchased from the American Type Culture Collection (Manassas, VA). The lines were propagated at $37{ }^{\circ} \mathrm{C}$ in an atmosphere of $5 \% \mathrm{CO}_{2}$ in air. The medium was Roswell Park Memorial Institute (RPMI) 1640 supplemented with fetal bovine serum (10\%), penicillin (100 units/ml), and streptomycin $(100 \mu \mathrm{g} / \mathrm{ml})$. Cells in log phase growth were harvested by 
trypsinization and washed twice with phosphate-buffered saline (PBS) to remove all traces of enzyme. A total of 5000 cells were seeded per well of a 96-well clear, flat-bottom plate (Microtest $96^{\circledR}$, Falcon) and incubated overnight $\left(37^{\circ} \mathrm{C}\right.$ in $\left.5 \% \mathrm{CO}_{2}\right)$. Samples dissolved in DMSO were then diluted and added to the appropriate wells (concentrations: $25 \mu \mathrm{g} / \mathrm{ml}, 5 \mu \mathrm{g} / \mathrm{ml}$, $1 \mu \mathrm{g} / \mathrm{ml}, 0.2 \mu \mathrm{g} / \mathrm{ml}, 0.04 \mu \mathrm{g} / \mathrm{ml}$; total volume: $100 \mu \mathrm{L}$; DMSO: $0.5 \%$ ). The cells were incubated in the presence of test substance for $72 \mathrm{~h}$ at $37^{\circ} \mathrm{C}$ and evaluated for viabilitywith a commercial absorbance assay (CellTiter $96^{\circledR}$ AQueous One Solution Cell ProliferationAssay, Promega Corp, Madison, WI) that measured viable cells. Activity was expressed by molarity relative to the negative (solvent) control. The positive control was vinblastinetested at $1 \mathrm{nM}$ in MDA-MB-435 cells, which had 48\% viable cells after treatment; $10 \mathrm{nM}$ in SW-620, which had $30 \%$ viable cells after treatment.

\subsection{Microbial strains, culture conditions, and preparation of inocula for susceptibility testing}

Strains of Escherichia coli strain C (ATCC 13706), Staphylococcus aureus (ATCC 6538) and Mycobacterium smegmatis (ATCC 607) were obtained from the American Type Culture Collection (ATCC). Saccharomyces cerevisiae, Candida albicans, Cryptococcus neoformans, Aspergillus niger and Micrococcus luteus strains were obtained from the Virginia Tech Microbiology teaching culture collection. Colonies of E. coli, S. aureus, M. luteus, S. cerevisiae, C. albicans and C. neoformans were grown on 1/10-strength Brain Heart Infusion Broth (BBL Microbiology Systems, Cockeysville, MD, USA) containing 0.2\% (w/v) sucrose (BHIB t S) and $1.5 \%(\mathrm{w} / \mathrm{v})$ agar. M. smegmatis was grown on Middlebrook 7 H10 agar (BBL Microbiology Systems) and $A$. niger on potato dextrose agar (PDA; BBL Microbiology Systems). Streaked plates were incubated at $378{ }^{\circ} \mathrm{C}$ for 3-7 days, except for that of $A$. niger, which was incubated in the dark at $30^{\circ} \mathrm{C}$. A single colony for each microbeexcept $A$. niger was used to inoculate $5 \mathrm{~mL}$ of 1/10-strength BHIB + S (E. coli, M. luteus, and S. aureus), Middlebrook $7 \mathrm{H} 9$ broth ( $M$. smegmatis) or yeast extract peptone maltosebroth (S. cerevisiae, C. albicans and C. neoformans) and incubated at $37{ }^{\circ} \mathrm{C}\left(S\right.$. cerevisiaeand M. luteus at $\left.30^{\circ} \mathrm{C}\right)$ for $4-7$ days. After growth, the resulting broth cultures were diluted with buffered saline gelatin [BSG; gelatin $(0.1 \mathrm{~g} / \mathrm{L}), \mathrm{NaCl}$ $\left.(8.5 \mathrm{~g} / \mathrm{L}), \mathrm{KH}_{2} \mathrm{PO}_{4}(0.3 \mathrm{~g} / \mathrm{L}), \mathrm{Na}_{2} \mathrm{HPO}_{4}(0.6 \mathrm{~g} / \mathrm{L})\right]$ to equal the turbidity of a no. $1 \mathrm{McF}$ arland standard. To check for viability and contamination, broth cultures were streaked on plate count agar (BBL Microbiology Systems); the plates were incubated at $37^{\circ} \mathrm{C}$ for $3-4$ days. Plates for $M$. luteus and $S$. cerevisiae were grown at $30^{\circ} \mathrm{C}$. Spores of $A$. niger were scraped from the surface of the PDA and suspended in $5 \mathrm{~mL}$ of $1 / 10$-strength BHIB $+\mathrm{S}$ and that suspension transferred to a sterile test tube. The turbidity was adjusted to be equivalent to that of a no. 1 McFarland standard by dilution with BSG. To check for viability and contamination, those spore suspensions were streaked on PDA and incubated at $37^{\circ} \mathrm{C}$ for $3-4$ days.

\subsection{Measurement of antimicrobial activity}

The minimal inhibitory concentrations (MICs) of the isolated compounds were measured by broth microdilution in 96-well microtitre plates. A 2-fold dilution series of the compounds was prepared in 96 -well microtitre plates in a $50 \mu \mathrm{L}$ volume of $1 / 10$-strength $\mathrm{BHIB}+\mathrm{S}$ and the dilution series was inoculated with $50 \mu \mathrm{L}$ of each cell suspension. The resulting inoculated dilution series were incubated at either 30 or $37^{\circ} \mathrm{C}$ (same as growth temperature) and growth, as turbidity, scored visually and recorded on the fourth day. MIC of each compound was measured 
in triplicate and was defined as the lowest concentration of drug resulting in a complete absence of turbidity compared with the drug-free control.

3.7. In vitro human prostatic $17 \beta$-hydroxysteroid dehydrogenase and $5 \alpha$-reductase assays of withaferin A

The in vitro $17 \beta-\mathrm{HSD}$ and $5 \alpha-\mathrm{R}$ activity assays were carried out using the membrane fraction obtained from human prostate homogenates, as described previously (Cabeza et al., 2009, Cabeza et al., 2011, Hirosumi et al., 1995).

\section{Conclusions}

Phytochemical investigation of the ethanolic extract of the leaves of $W$. obtusifolia resulted in the isolation of seven withanolides (1-7), namely obtusifonolide (1), sitoindoside IX (2), 6 $\alpha$-chloro5ß-hydroxy withaferin A (3), isowithanone (4), 2,3-dihydro-3-ethoxywithaferin A (5), daturataturin A (6), and withaferin A (7). The cytotoxic activity of compounds 1-7 was assessed against two cancer cell lines, MDA-MB-435 and SW-620. Compound 7 was the most potent with $\mathrm{IC}_{50}$ values of 1.7 and $0.3 \mu \mathrm{M}$, respectively. Moreover, withaferin A (7) stimulated the activity of $17 \beta$-hydroxysteroid dehydrogenase and $5 \alpha$-reductase in vitro.

\section{Acknowledgments}

This research was supported by Deanship of Research, Jordan University of Science and Technology, Irbid, Jordan. The high resolution mass spectrometry data were acquired at the Triad Mass Spectrometry Laboratory at the University of North Carolina at Greensboro.

\section{References}

Alali, F.Q., El-Elimat, T., Li, C., Qandil, A., Alkofahi, A., Tawaha, K., Burgess, J.P., Nakanishi, Y., Kroll, D.J., Navarro, H.A., Falkinham 3rd, J.O., Wani, M.C., Oberlies, N.H., 2005. New colchicinoids from a native Jordanian meadow saffron, Colchicum brachyphyllum: isolation of the first naturally occurring dextrorotatory colchicinoid. J. Nat. Prod. 68, 173-178.

Alali, F.Q., Gharaibeh, A.A., Ghawanmeh, A., Tawaha, K., Qandil, A., Burgess, J.P., Sy, A., Nakanishi, Y., Kroll, D.J., Oberlies, N.H., 2010. Colchicinoids from Colchicum crocifolium boiss. (Colchicaceae). Nat. Prod. Res. 24, 152-159.

Alali, F.Q., Tahboub, Y.R., Ibrahim, E.S., Qandil, A.M., Tawaha, K., Burgess, J.P., Sy, A., Nakanishi, Y., Kroll, D.J., Oberlies, N.H., 2008. Pyrrolizidine alkaloids from Echium glomeratum (Boraginaceae). Phytochemistry 69, 2341-2346.

Atta-ur-Rahman, Choudhary, M.I., Yousaf, M., Gul, W., Qureshi, S., 1998. New withanolides from Withania coagulans. Chem. Pharm. Bull. 46, 1853-1856.

Atta-ur-Rahman, Dur-e-Shahwar, Naz, A., Choudhary, M.I., 2003. Withanolides from Withania coagulans. Phytochemistry 63, 387-390. 
Bonkhoff, H., Stein, U., Aumuller, G., Remberger, K., 1996. Differential expression of 5 alphareductase isoenzymes in the human prostate and prostatic carcinomas. Prostate 29, 261-267.

Cabeza, M., Trejo, K.V., Gonzalez, C., Garcia, P., Soriano, J., Heuze, Y., Bratoeff, E., 2011. Steroidal 5 alpha-reductase inhibitors using 4-androstenedione as substrate. J. Enzyme Inhib. Med. Chem. 26, 712-719.

Cabeza, M., Zambrano, A., Heuze, I., Carrizales, E., Palacios, A., Segura, T., Valencia, N., Bratoeff, E., 2009. Novel c-6 substituted and unsubstituted pregnane derivatives as 5 alphareductase inhibitors and their effect on hamster flank organs diameter size. Steroids 74, 793-802.

Chen, L.X., He, H., Qiu, F., 2011. Natural withanolides: an overview. Nat. Prod. Rep. 28, 705740 .

Esposito, D., Komarnytsky, S., Shapses, S., Raskin, I., 2011. Anabolic effect of plant brassinosteroid. FASEB J. 25, 3708-3719.

Geissler, W.M., Davis, D.L., Wu, L., Bradshaw, K.D., Patel, S., Mendonca, B.B., Elliston, K.O., Wilson, J.D., Russell, D.W., Andersson, S., 1994. Male pseudohermaphroditism caused by mutations of testicular 17-beta-hydroxysteroid dehydrogenase-3. Nat. Genet. 7, 34-39.

Ghosal, S., Kaur, R., Srivastava, R.S., 1988. Sitoindosides ix and x, new glycowithanolides from Withania somnifera. Indian J. Nat. Prod. 4, 12-13.

Glotter, E., 1991. Withanolides and related ergostane-type steroids. Nat. Prod. Rep. 8, 415-440.

Hirosumi, J., Nakayama, O., Fagan, T., Sawada, K., Chida, N., Inami, M., Takahashi, S., Kojo, H., Notsu, Y., Okuhara, M., 1995. Fk143, a novel nonsteroidal inhibitor of steroid 5-reductase. 1. In-vitro effects on human and animal prostatic enzymes. J. Steroid Biochem. Mol. Biol. 52, 357363.

Kupchan, S.M., Doskotch, R.W., Bollinger, P., McPhail, A.T., Sim, G.A., Renauld, J.A., 1965. The isolation and structural elucidation of a novel steroidal tumor inhibitor from Acnistus arborescens. J. Am. Chem. Soc. 87, 5805-5806.

Lala, P., Misra, L., Sangwan, R.S., Tuli, R., 2006. New withanolides from fresh berries of Withania somnifera. Z. Naturforsch. C 61b, 1143-1147.

Lavie, D., Glotter, E., Shvo, Y., 1965. Constituents of Withania somnifera dun. III. The side chain of withaferin A. J. Org. Chem. 30, 1774-1778.

Lanos, G.G., Araujo, L.M., Jimenez, I.A., Moujir, L.M., Vazquez, J.T., Bazzocchi, I.L., 2010. Withanolides from Withania aristata and their cytotoxic activity. Steroids 75, 974-981. 
Marberger, M., 2006. Drug insight: 5 alpha-reductase inhibitors for the treatment of benign prostatic hyperplasia. Nat. Clin. Pract. Urol. 3, 495-503.

Misico, R.I., Nicotra, V.E., Oberti, J.C., Barboza, G., Gil, R.R., Burton, G., 2011. Withanolides and related steroids. Fortschr. Chem. Org. Naturst. 94, 127-229.

Misra, L., Lal, P., Sangwan, R.S., Sangwan, N.S., Uniyal, G.C., Tuli, R., 2005. Unusually sulfated and oxygenated steroids from Withania somnifera. Phytochemistry 66, 2702-2707.

Nittala, S.S., Velde, V.V., Frolow, F., Lavie, D., 1981. Chlorinated withanolides from Withania somnifera and Acnistus breviflorus. Phytochemistry 20, 2547-2552.

Pelletier, S.W., Mody, N.V., Nowacki, J., Bhattacharyya, J., 1979. Carbon-13 nuclear magnetic resonance spectral analysis of naturally occurring withanolides and their derivatives. J. Nat. Prod. 42, 512-521.

Peltoketo, H., Luu-The, V., Simard, J., Adamski, J., 1999. 17 beta-hydroxysteroid dehydrogenase (HSD)/17-ketosteroid reductase (KSR) family; nomenclature and main characteristics of the 17HSD/KSR enzymes. J. Mol. Endocrinol. 23, 1-11.

Ray, A.B., Gupta, M., 1994. Withasteroids, a growing group of naturally occurring steroidal lactones. In: Herz, W., Kirby, G.W., Moore, R.E., Steglich, W., Tamm, C. (Eds.), Progress in the Chemistry of Organic Natural Products, vol. 63. Springer Verlag, New York, NY, USA, pp. 1106.

Samadi, A.K., Tong, X., Mukerji, R., Zhang, H., Timmermann, B.N., Cohen, M.S., 2010. Withaferin A, a cytotoxic steroid from Vassobia breviflora, induces apoptosis in human head and neck squamous cell carcinoma. J. Nat. Prod. 73, 1476-1481.

Sangwan, R.S., Das Chaurasiya, N., Lal, P., Misra, L., Tuli, R., Sangwan, N.S., 2008. Withanolide a is inherently de novo biosynthesized in roots of the medicinal plant ashwagandha (Withania somnifera). Physiol. Plant. 133, 278-287.

Shingu, K., Yahara, S., Nohara, T., 1990. New withanolides, daturadaturins A and B from Datura tatura L. Chem. Pharm. Bull. 38, 3485-3487.

Thomas, L.N., Lazier, C.B., Gupta, R., Norman, R.W., Troyer, D.A., O'Brien, S.P., Rittmaster, R.S., 2005. Differential alterations in 5 alpha-reductase type 1 and type 2 levels during development and progression of prostate cancer. Prostate 63, 231-239.

Zhang, H.P., Samadi, A.K., Gallagher, R.J., Araya, J.J., Tong, X.Q., Day, V.W., Cohen, M.S., Kindscher, K., Gollapudi, R., Timmermann, B.N., 2011. Cytotoxic withanolide constituents of Physalis longifolia. J. Nat. Prod. 74, 2532-2544. 
Appendix A. Supplementary data

Bioactive withanolides from Withania obtusifolia

Feras Q. Alali, Chiraz Soumia M. Amrine, Tamam El-Elimat, Ahmad Alkofahi, Khaled Tawaha, Mohammad Gharaibah, Steven M. Swanson, Joseph O. Falkinham III, Marisa Cabeza, Araceli Sánchez, Mario Figueroa, and Nicholas H. Oberlies

Fig. S1. UPLC chromatograms of compounds 1-7 (ELSD detection).

Fig. S2. ${ }^{1} \mathrm{H}$ NMR spectrum of obtusifonolide (1) $\left[500 \mathrm{MHz}, \mathrm{CDCl}_{3}\right]$.

Fig. S3. ${ }^{13} \mathrm{C}$ NMR spectrum of obtusifonolide (1) [125 $\mathrm{MHz}, \mathrm{CDCl}_{3}$ ].

Table S1. Antimicrobial activities of compounds (1-7). 

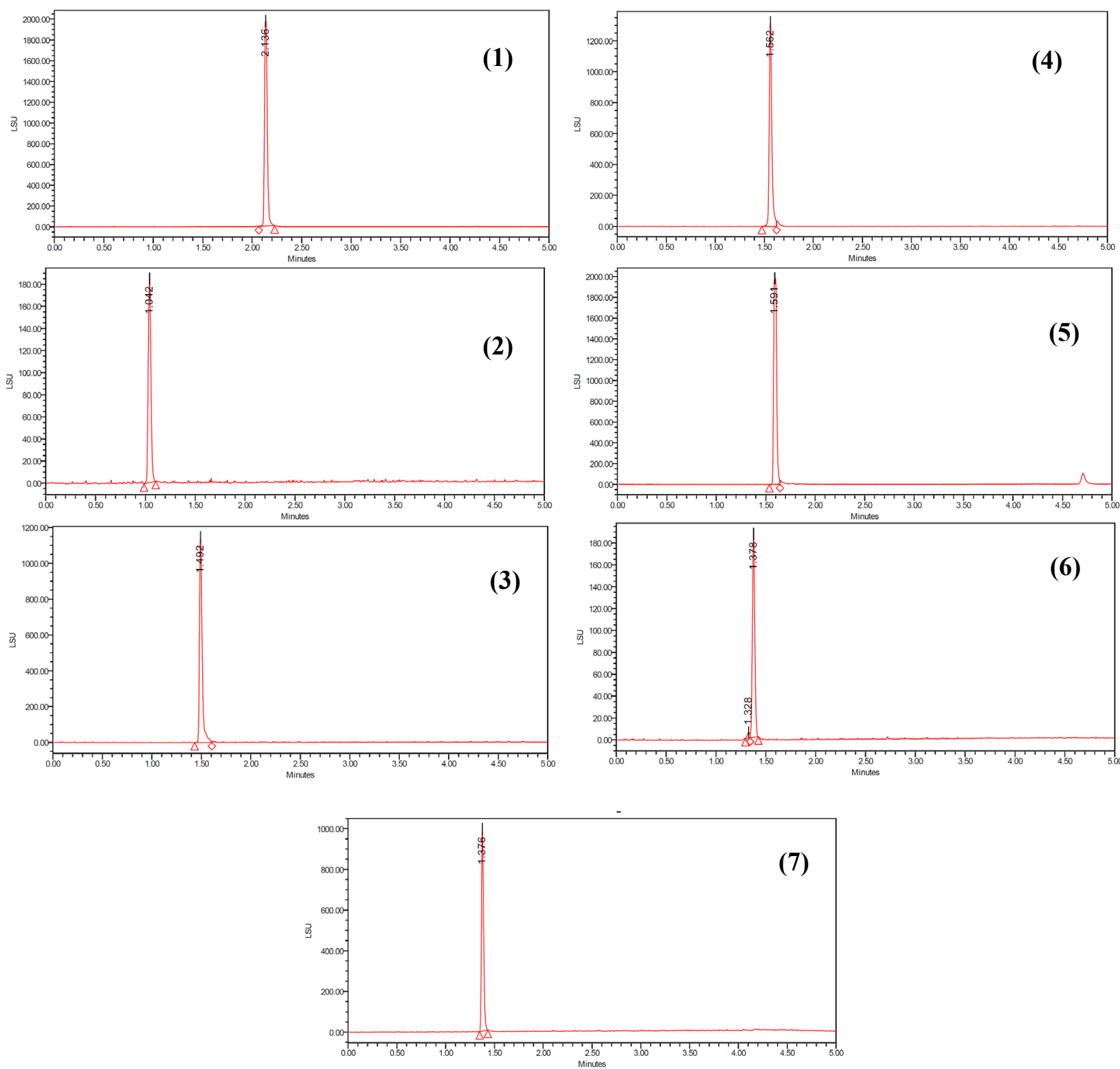

Fig. S1. UPLC chromatograms of compounds 1-7 (ELSD detection). 


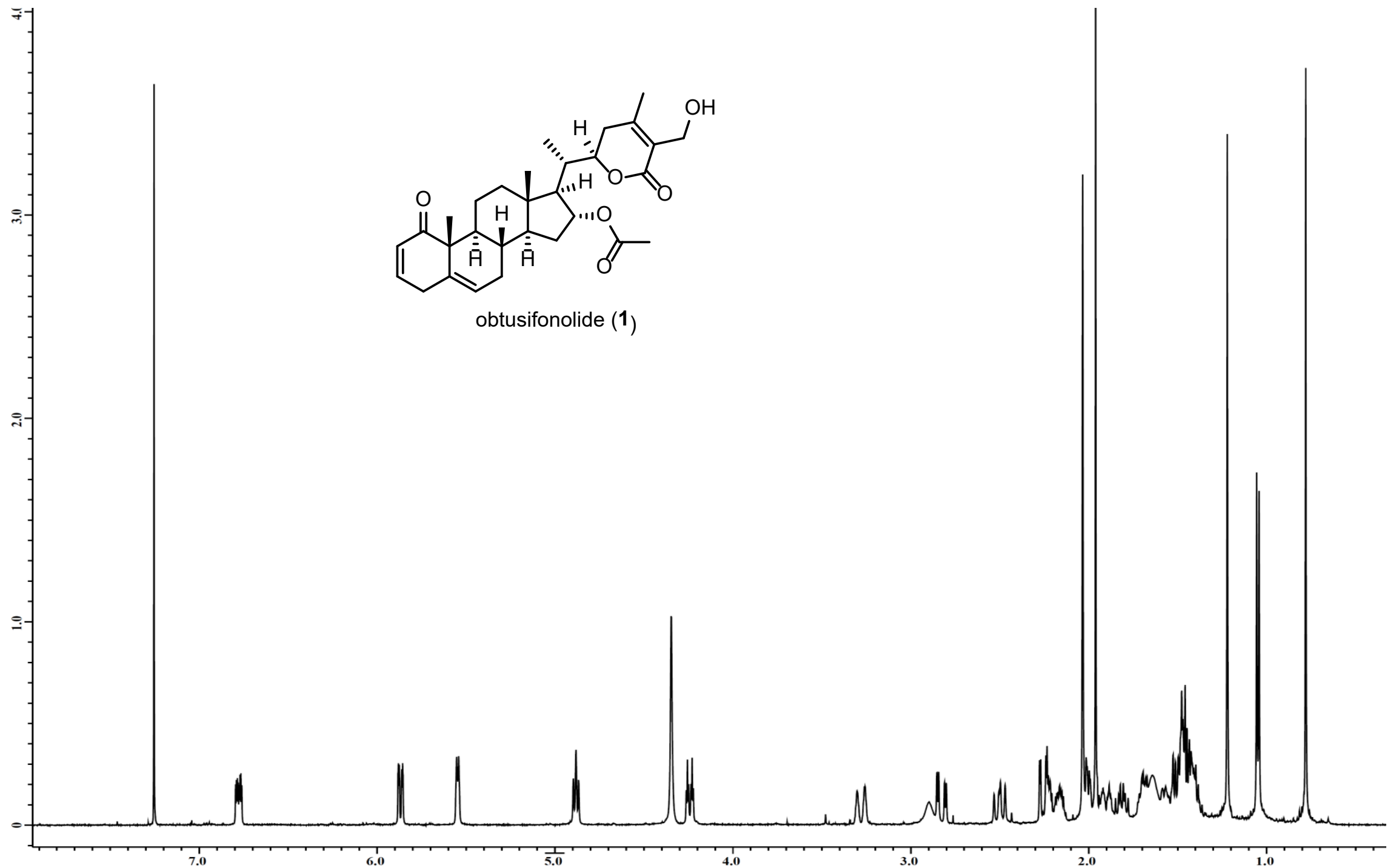

Fig. S2. ${ }^{1} \mathrm{H}$ NMR spectrum of obtusifonolide (1) [500 $\left.\mathrm{MHz}, \mathrm{CDCl}_{3}\right]$. 


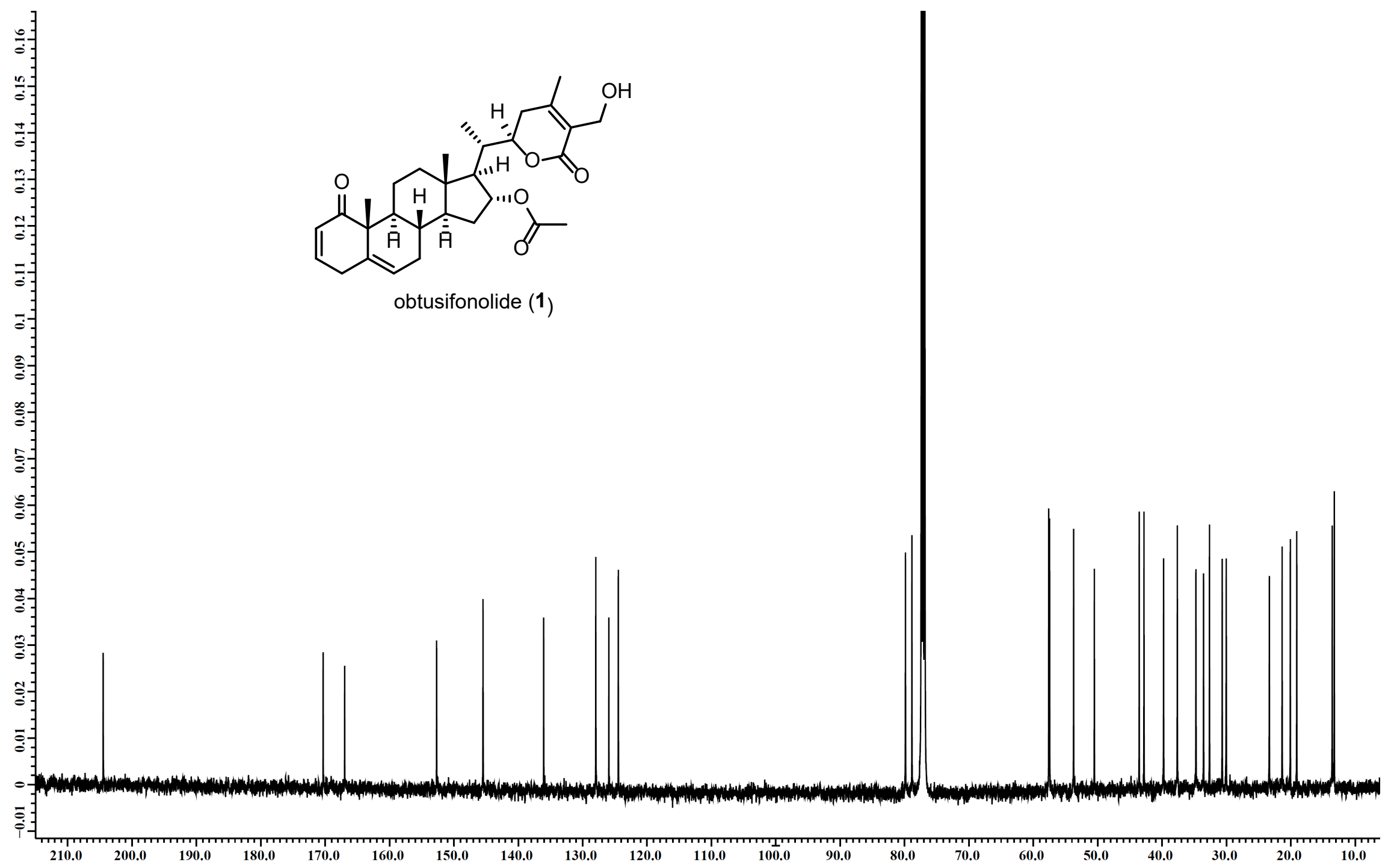

Fig. S3. ${ }^{13} \mathrm{C}$ NMR spectrum of obtusifonolide (1) [125 MHz, $\left.\mathrm{CDCl}_{3}\right]$. 
Table S1

Antimicrobial activities of compounds (1-7)

\begin{tabular}{|c|c|c|c|c|c|c|c|c|}
\hline \multirow[t]{2}{*}{ compound } & \multicolumn{8}{|c|}{ Minimal inhibitory activity $(\mu \mathrm{g} / \mathrm{ml})$} \\
\hline & M. luteus & S. aureus & E. coli & M. smegmatis & S. cerevisiae & C. albicans & C. neoformans & A. niger \\
\hline 1 & $>60$ & $>60$ & $>60$ & $>60$ & $>60$ & $>60$ & $>60$ & $>60$ \\
\hline 2 & $>95$ & $>95$ & $>95$ & $>95$ & $>95$ & $>95$ & $>95$ & $>95$ \\
\hline 3 & $>75$ & $>75$ & $>75$ & $>75$ & $>75$ & $>75$ & $>75$ & $>75$ \\
\hline 4 & $>70$ & $>70$ & $>70$ & $>70$ & $>70$ & $>70$ & $>70$ & $>70$ \\
\hline 5 & $>55$ & $>55$ & $>55$ & $>55$ & $>55$ & $>55$ & $>55$ & $>55$ \\
\hline 6 & $>128$ & $>128$ & $>128$ & $>128$ & $>128$ & $>128$ & $>128$ & $>128$ \\
\hline 7 & 19 & 19 & $>75$ & $>75$ & $>75$ & $>75$ & $>75$ & $>75$ \\
\hline Vancomycin & NT & 0.25 & NT & NT & NT & NT & NT & NT \\
\hline Ampicillin & NT & NT & 8 & NT & NT & NT & NT & NT \\
\hline Ciprofloxacin & NT & NT & NT & 2.0 & NT & NT & NT & NT \\
\hline Amphotericin B & NT & NT & NT & NT & NT & 25 & 25 & 100 \\
\hline NT: not tested & & & & & & & & \\
\hline
\end{tabular}

